\title{
Incorporating Computers into Classroom: Effects on Learners' Reading Comprehension in EFL Context
}

Ali Akbar Ansarin ${ }^{1}$, Farahman Farrokhi ${ }^{1}$, Hamid Reza Mahboudi ${ }^{2 *}$

${ }^{1}$ Department of Foreign Languages and Literature, University of Tabriz, Tabriz, Iran

${ }^{2}$ Department of Social Sciences, University College of Rubbi Rashid, Tabriz, Iran

Corresponding Author: Hamid Reza Mahboudi, E-mail: hr_mahboodi@yahoo.com

\section{ARTICLE INFO}

Article history

Received: June 29, 2017

Accepted: July 25, 2017

Published: December 01, 2017

Volume: 6 Issue: 7

Special Issue on Language \& Literature Advance access: September 2017

Conflicts of interest: Non

Funding: None

\begin{abstract}
Owing to the importance of computer-assisted reading and considering the prominent role of learners in this respect, the present study investigated: (1) the effects of computer as a supplemental tool to support and improve the Iranian EFL learners' reading comprehension in comparison with equivalent non-technological or traditional print-based treatments, (2) EFL learners' attitudes and perception towards the computer-assisted reading course.To this purpose, 111 randomly selected groups of EFL learners participated in the study. The subjects were divided into two groups of control and experimental. Both groups received 10 reading lessons either through computers or through an instructor-led method. The statistical analysis revealed no significant difference between the learners who had access to reading supports on computer screen and their counterparts in the traditional reading classes. Learners were also allowed to express their ideas on a 5-point Likert Scale. The purpose of the attitude questionnaire was to find out more information about the participants and their experiences with computer-assisted reading. Results of attitude questionnaire supported the conclusion that computers may enhance EFL learners' motivation and interest towards learning but they do not enhance comprehension. The findings of this study support the view that technology should supplement not supplant teachers and that people read less accurately and less comprehensively on screens than on paper.
\end{abstract}

Key words: Computer-assisted Reading, Traditional Reading, EFL Learner, Attitude

\section{INTRODUCTION}

Traditionally, reading instruction has involved either direct instruction on decoding skills or informal teaching of comprehension. However, recent research on the process of text comprehension supported that text comprehension can be facilitated by multimedia aids such as pictures, animations, and other visual or auditory cues. Though they are independent of the presentation mode of the text, multimedia aids support the process text comprehension (Chun \& Plass, 1997: 71).

In line with this, with the arrival of computer-assisted language learning, technology has promised to support good pedagogical practice, promoting cognitive processing and increasing the power of the learning experience. Besides, in order for students to develop into fluent adult readers, they have to acquire motivation, strategies, knowledge, and social interaction. Students can learn to read if provided with appropriate instructional reading strategies (Akyle \& Ercetin, 2009). Researching the effectiveness of new strategies, utilizing technology will assist the classroom in improvement of reading (Lomika, 1998). Technology presents new ways to present information in a motivating format for the audience. Thus confidence is raised in the students
Regarding computers, their advantages to general learning have been reported to be much the same for language learning. Montali and Lewandowski (1996) reviewed studies conducted with first-language secondary-school students favoring multimedia as a way of improving reading skills among average and less-skilled readers. They suggested that readers who enjoy reading tend to read more and are more motivated to read and that a computer can be useful in promoting interests.

On the other hand, The RAND Reading Study Group (RRSG, 2002) reported, "electronic texts that incorporate hyperlinks and hypermedia require skills and abilities beyond those required for the comprehension of conventional, linear print" (p. 14). Others have speculated that previous research on traditional comprehension strategies can inform, but not complete, our understanding of online reading comprehension (see Coiro, 2003; Hartman, Morsink, \& Zheng, 2010; Leu, Kinzer, Coiro, \& Cammack, 2004; Spires \& Estes, 2002).

According to Winograd, Paris \& Bridge (1991), poor readers may harbor such anxiety about their abilities and expected failure that many will intentionally and painstakingly avoid reading. Bimodal reading instruction may in- 
crease a child's motivation by providing a more successful reading experience for youngsters with disabilities. Moreover, Montali and Lewandowski (1996) demonstrated that poor readers not only feel more successful with bimodal presentation, but are more successful in terms of comprehending content. This type of reading program delivered via computer may offer one solution to some of the problems educators encounter with students who display reading difficulties

In general, most published scientific research show that researchers and educational linguists seem to hold the view that reading comprehension can be facilitated by multimedia aids and that they stress the importance of computerized reading. However, there exist some gaps in these studies which are aimed to be filled by the present study. These studies attempted to generalize their findings from high-source settings and did not examine whether learners in low-source settings could also enjoy the benefits of using technology in the classroom to facilitate reading comprehension.

This study is of great importance, especially in Iranian EFL context, in contributing to the current literature on English teaching and learning research, CALL research and applications. As Dillon (1992) concluded, the impact of presentation medium on reading comprehension outweighs the issue of reading fluenc. The impact of Visual Display Unit (VDU) would be strongly restricted if there were a strong relationship between reading on screen and reduced comprehension. Since devising a suitable means of measuring reader's comprehension is difficult, more research is necessary to address the issue. (p.1305)

The study also has the potential to determine if the advantages of computer application will improve EFL students' reading skills. What is becoming increasingly clear, however, is that while most educational contexts in Iran do not use computers in reading classes, and if used, they are not taken seriously; many other teachers still follow a traditional approach to teaching reading and mainly focus on teaching rather than learning.

\section{Objectives of the Study}

As part of a Ph.D. dissertation, this study aims to compare the effects of computer as a supplemental tool to support and improve the Iranian EFL learners' reading comprehension with equivalent non-technological or traditional print-based treatments. The study also seeks to investigate EFL learners' attitudes towards the computerized reading in comparison to traditional print- based reading.

Therefore, the objectives of the study can be described as follows:

1. To compare the effects of computer as a supplemental tool to support and improve the Iranian EFL learners' reading comprehension with equivalent non-technological or traditional print-based treatments.

2. To examine the EFL learners' attitudes towards the computerized reading in comparison to traditional print- based reading.

\section{LITERATURE REVIEW}

For many university foreign students reading skills are perhaps more important for academic success than speaking ability. Reading is a skill that everyone needs whether $\mathrm{s} / \mathrm{he}$ is elementary, secondary, or adult school. Yet it is a skill that gets slighted in most ESL teacher-training programs (Hatch, 1978). As Alemi \& Ebadi (2010) argue, although there is abundant research about reading in a first or second language, most writers contend that there is very little information about the reading process and perhaps much less about different ways of facilitating it.

In line with this, Kleinman (1987) also claims that in spite of advancements in our understanding of the reading process, reading instruction has advanced very little beyond the type of instruction provided for students thirty years ago. Carrell (1985) lists three groups of students for whom English reading becomes crucial, namely, those in EFL context, those at advanced levels of proficienc , and those who need English for academic purposes. Nunan (1995: 65) argues that the reader is at the core of reading process. Therefore, teachers and linguists should prioritize the reader's mental process, i.e. the way the reader arrives at the meaning, in their studies.

By means of computers, tablets, smart phones and social media, people communicate more easily throughout the world. Moreover, the rampant growth of technology makes "the world flattened". As Friedman (2005) argues "The world is being leveled" (p.8); and this leveling process keeps continuing every minute. It makes no difference where people are, in Iran, in Turkey, or in America, they can have contact with people around the world without delay; and this communication occurs through mobile technology and inevitably the Internet. As for the field of education, more importance is being given to study and research the integration of technology. However, the first question is whether faculty and students would welcome the integration of technology into their classrooms, i.e. some educationalists still express doubt about whether teachers who are "digital immigrants" are prepared to teach the generation in the $21^{\text {st }}$ century who is "digital natives". These two terms - digital immigrants and digital natives - were coined by Prensky (2001, p. 1). He states that "Our students have changed radically. Today's students are no longer the pupils our educational system was designed to teach". Watson (2010) expresses his concern with regard to the fact that technology influences teaching and learning:

Teachers may face a conflict of teaching and learning styles. Older teachers generally teach face to face and proceed in a logical or step-by-step basis. In contrast, younger students tend to jump around from one idea or thought to another and expect sensory-laden environments as a matter of course. They also want instant results and frequent rewards, whereas many teachers regard learning as slower and serious and consider that students should just keep quiet and listen. (p.15).

Along with the advancement of technological devices and their effect on education, old methods are replaced rapidly by new methods and Computer-Assisted Instruction 
(CAI) has been incorporated into the teaching-learning process to improve the quality of education. Further, there has been much tendency by English teachers to use the new technology in classrooms and apply these facilities in language teaching.

The second question is how faculty and EFL students, in case they welcome such integration, can best be formally equipped through technology to welcome delivery and implementation procedures and to overcome their misbeliefs and subsequent challenges. Moreover, integration of technology into the classrooms can help faculty, too. It helps them activate their own skills, prepare technology-based lesson plans, and create an instructional cyber environment, and predict and overcome Computer-Assisted Language Learning (CALL) problems. This implies that the integration of technology, both software and hardware can be delivered to pave the way for successful infusion of the knowledge gained into their EFL classrooms.

Throughout the last decade, the use of computers in educational settings has increased noticeably (Warschaucer, 1996). Meanwhile, application of computer assisted language learning has confronted a new start in the modern language teaching and learning field and has found many fans (Chapelle, 2001).

On the other hand, nowadays reading comprehension has been changed to the ability that influences the academic advances a lot. In schools and colleges where students' reading outcomes have gained importance, technology has played a prominent role in buttressing teachers and learners.

Educational researchers stress the importance of integrating technology into classrooms and curricula (Clements and Sarama, 2003; Glaubke 2007; National Association for the Education of Young Children (NAEYC) and Fred Rogers Center, 2012). Researchers are busy providing evidence in numerous projects to demonstrate the advantages of computer technology that relate to reading comprehension. Anderson-Inman and Horney (2007) contend that technology helps students cope with barriers imposed by paper-based reading, while Gajria et al. (2007) hold that application of technology may support teaching and increase positive motivation and comprehension.

At the same time, most studies imply that technology can slow down the progress of students in schools and colleges if educators do not incorporate them appropriately into their classrooms. Appropriate integration of technology entails knowledgeable, adaptable, committed teachers (Balajthy, 1999). "When teachers are well-trained and motivated, and when computer use is embedded in well-designed lesson plans, and when access to Disney and YouTube (and Facebook, and Twitter, and World of Warcraft) is disabled, information technology can be a useful adjunct to teaching." (Kenny, 2013) Therefore, technology is no "silver bullet", and it certainly can't save a broken school system. Computer technology is no cure for a "systemic education reform" which is messy and arduous work.

Furthermore research shows that the use of computer software and hardware should be encouraged in the teacher training courses and English teachers should be acquainted with merits of computer technology and its valuable impacts on language learning and be trained to implement technology in the classroom to empower themselves and enhance student learning.

In line with this, reading on screen entails new comprehension skills and strategies in addition to those needed when reading printed books (e.g. Afflerbach \& Cho, 2009; Hartman et al., 2010; Kingsley, 2011; Kuiper, 2007; Spires \& Estes, 2002). By highlighting that our students should become prepared for the future, Leu (2007) cautions against the danger of ignoring the fact that screen reading requires new skills and strategies.

\section{METHODOLOGY}

This study aims to investigate whether using computer offering aids such as hyperlinks, images, animation, hypermedia, and glosses in reading passages on the screen would help them comprehend the online reading passages better than the students who are engaged in the comprehending of the same conventional, linear print of offline reading passages with the help of teacher.

\section{Research Question and Hypothesis}

This study aims at addressing the following research question and hypotheses:

RQ1: Does computer integration have any effect on EFL learners' reading comprehension?, or, Is there any difference between the reading comprehension of learners who read online texts with the aid of computer glosses, hypertexts and hypermedia and those who read them offline in print without such aids

H0: Computer integration has no effect on the learners' reading comprehension.

RQ2: What are the students' attitudes towards the computerized reading in comparison to traditional print based reading?

\section{Participants}

The participants comprising the population of this study were 111 EFL learners majoring in English translation, biotechnology, biology, biochemistry, microbiology, and genetics. They were all volunteers who were given an equal chance to take part in the study.

The participants were divided into two groups according to their performance on the TOEFL Junior Standard Test: an experimental group consisting of 57 students and a control group consisting of 54 students. The variables of age and sex were not controlled in the study.

\section{Instruments}

\section{Homogeneity test}

For any research to be valid, it is essential to guarantee the participants' homogeneity. A placement test (TOEFL Junior, 2012; Appendix 1) was administered to ascertain that the participants were at the same level and there was no significant difference between groups. The test was an objective 
one, containing 84 multiple choice questions to identify the optimal level for students entering the language program.

\section{Online reading passages}

Ten reading passages were chosen from the book "An Anthology of Collegiate Readings" compiled by the researcher (2010) intended for the students doing Basic English one and two as well as General English courses at the University College of Rubbi Rashid in Tabriz, Iran. Each passage is accompanied by questions of different kinds including reading comprehension questions and vocabulary questions. The content of the reading passages is graded and interesting and somewhat similar to the materials presented in Virtual Language Center (VLC) and California Distance Learning Project (CDLP). Participants also enjoyed the benefits of Merit Software reading passages. This software is web-based reading comprehension software used by colleges and schools to improve their students reading and writing program. The software is suitable for elementary, middle, and high school students.

The materials were compiled for reading comprehension courses so the researcher preferred to use the materials in devising the online reading course for the experimental group. The words in the onscreen reading passages had been provided with glossing to attract the participants' attention so that they could click on the highlighted word which was also accompanied with pronunciation. Participants had to search the relevant sites for further information about the new words, such as Longman English Dictionary Online, Merriam Webster and thesaurus and Wikipedia.

The researcher's reading software had been developed by a software developer who was requested to replicate the top-rated reading soft wares such as Merit Software and Reader's Edge. The hypermedia texts were chosen from "An Anthology of Collegiate Readings" compiled by the researcher intended for EFL students at the intermediate level. The authenticity of the source texts were retained, since no linguistic or semantic modifications were made

The newly developed reading software had the same qualities, for example, participants could click on the listen button and listen and read the passages, click to check their answers to comprehension and vocabulary questions, click to see the dictionary definitions, and click to check spelling.

The free online software tool, Readability Calculator (Adamovic, 2009), was used to calculate readability and to ascertain the suitability of the passages for the proficiency level of the participants. This includes Coleman Liau index, the Flesh Kincaid Grade level, ARI (Automated Readability Index), and SMOG. These measures represent the required U.S. grade level. They ranged from 5.6-9.8

The readability indexes of the assigned materials are presented in Table 1.

\section{Reading passages in printed form}

The same number of reading passages which had been devised for experimental group was provided in printed format by the researcher. They included the same reading passages with the same accompanying questions and exercises.

\section{Online resources and reading software}

The computerized reading passages were supported by such online resources as world wide web (WWW), google search, google translator, pronunciation guide (audio and video), the free encyclopedia, pictures, slides, glosses, videos, animations, and other web resources so that the teacher's role was reduced to a minimum.

Some other texts were chosen from Merit Software, the distance learning sites, such as California Distance Learning project (CDLP) and Virtual Language Center (VLC).

\section{Background questionnaire (Questionnaire A)}

After assigning the students into subgroups, the experimental group filled out a background questionnaire (Appendix A) in the first session. Responding to this questionnaire the participants gave some demographic information on their age and gender, their ability in using the computer before this course, and their expectations and predictions of success in this course. The questions were answered based on two options: Yes/No.

\section{Attitude questionnaire (Questionnaire B)}

After ten sessions of treatment, the participants in the experimental group filled out an attitude questionnaire (Appendix B). The purpose of the attitude questionnaire was to find out more information about the participants and their experiences with computer-assisted reading. The items were related to the participants' experience with technology, in general, and usefulness and ease or difficulty of use of certain features of the program, in particular.

In this questionnaire the test takers were allowed to express their ideas on a 5-point Likert Scale in following terms: 1 (strongly agreed), 2 (agreed), 3 (no idea), 4 (disagreed), 5 (strongly disagreed). The questions were all closed, so as to facilitate easier analysis of the results. The complete list of the questions can be found in Appendix B.

\section{Procedure}

The following steps were taken to carry out the study:

1. Reading passages in printed form

The first step to conduct the study was to decide on the homogeneity of the participants. After the administration and analyzing the results, the participants were randomly divided into two groups of control and experi-

Table 1. Readability indexes of the assigned materials

\begin{tabular}{lcccccccccc}
\hline Passage & $\mathbf{1}$ & $\mathbf{2}$ & $\mathbf{3}$ & $\mathbf{4}$ & $\mathbf{5}$ & $\mathbf{6}$ & $\mathbf{7}$ & $\mathbf{8}$ & $\mathbf{9}$ & $\mathbf{1 0}$ \\
\hline Readability index & 5.6 & 6.2 & 6.7 & 6.9 & 7.1 & 7.7 & 7.9 & 8.3 & 9 & 9.1 \\
\hline
\end{tabular}


mental group, and there were 54 students in the control group and 57 students in the experimental group.

The researcher met the participants in the control group once a week for two hours each session, totally 48 hours during the study- 24 hours during 12 weeks for the control group and 24 hours for the experimental group. All the sessions were scheduled in the mornings and the researcher was the instructor. Due to their large number, the control group was divided in two, but their classes were held consecutively.

The physical setting of the control group was a conventional classroom. The students sat in pairs facing the whiteboard and the teacher. The researcher started the reading course with a brief introduction about the importance of reading comprehension and its significance for university students and what they were going to do throughout the course.

2. Answering background questionnaire

Before starting the course, the experimental group was required to answer the questions with marking YES/NO.

3. Reading passages on the computer screen

After completing the background questionnaire, the students in the experimental group were seated in front of computers. They had the same number of sessions but they experienced the reading passages in a different format from those of the control group throughout the study. Similar to the control group, the experimental group was divided into two due to the facilities required for conducting the classes with computer. The classes were also held consecutively.

A whole session was spent on how to use the keyboard and the computer. They were given some instruction on how to google search and how to use the online dictionaries, Wikipedia, thesaurus, pronunciation guide, google translator, pictures, glosses and animations, the search engine, and the reading software. Nearly all the students knew how to use the keyboard; however, the teacher was always ready to help those who were apparently slower to gain autonomy after the first few sessions

4. Answering the attitude questionnaire

In the last session of the experiment, the students were given a questionnaire to express their opinions and attitudes toward the program. In this questionnaire the test takers were allowed to express their ideas on a 5-point Likert Scale in following terms: 1 (strongly agreed), 2 (agreed), 3 (no idea), 4 (disagreed), 5 (strongly disagreed).

\section{DATA ANALYSIS AND RESULTS}

The following section discusses the manipulation and analyses of data obtained from the homogeneity test, reading comprehension tests as well as attitude and background questionnaires. The study was exploratory in nature and focused on reading behavior and performance of EFL learners across two levels of language proficienc .

The data available for analysis comprised homogeneity test results, reading comprehension scores, and the information available in the questionnaires.
After scoring the tests and investigating the questionnaires, the results were analyzed to provide answers to research questions. SPSS version 18 was used in the analysis of the data. The findings were tabulated in terms of means and standard deviations. A t-test $(\mathrm{p}>0.05)$ was used for comparing the means of the reading passages scores of control and experimental groups. But first the equality of score variances was achieved through Leven's Test.

\section{Homogeneity Test}

A placement test (Appendix A) was administered to ascertain that the participants were at the same level of proficie cy and there were no significant difference between groups. The placement test was also used to assign subjects to two random groups.

Kolmogrov-Smirnov statistics (KS test) is one the numerical ways of assessing normal distribution of data in both control and experimental groups. (see Table 2)

The null hypothesis in KS test is the normality of distributions. Since the sig. is greater than 0.05 , the null hypothesis is confirmed and it is concluded that the samples follow a normal distribution.

Table 3 confirms the equality of variances in both control and experimental groups with Leven's Test with p-values of 0.747 and 0.199 which are greater than 0.05 . Analysis of mean scores of control and experimental groups at the two levels of proficiency shows no significant difference between the means. Figure 1 clearly demonstrates the equality of control and experimental groups at the two levels of proficienc.

Figure 1. Mean +1/-1 SD Placement Showing Lack of Difference between the Mean Scores of Control and Experimental Groups

\section{Results of Reading Comprehension Tests}

The overall description of 10 reading passages in terms of mean, standard deviation, minimum, and maximum scores of the students in both control and experimental groups is demonstrated in Table 4.

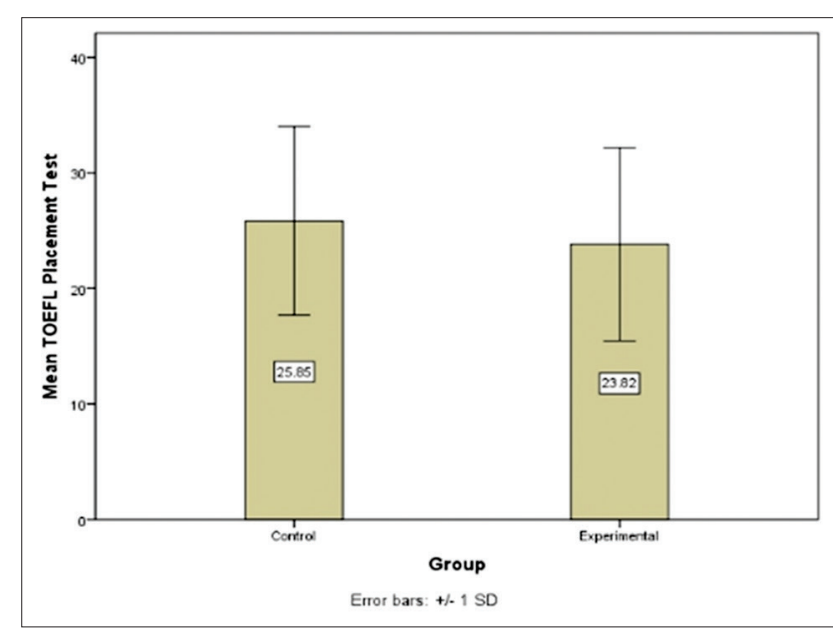

Figure 1. Mean $+1 /-1$ SD placement showing lack of difference between the mean scores of control and experimental groups 
Table 2. One-sample Kolmogorov-Smirnov test for normality test

\begin{tabular}{lccc}
\hline & $\boldsymbol{N}$ & Kolmogorov-Smirnov Z & Asymp. Sig. (2-tailed) \\
\hline TOEFL placement test & 111 & 1.251 & 0.088 \\
Reading passages scores & 111 & 0.705 & 0.704 \\
\hline
\end{tabular}

Table 3. T-test of homogeneity of control and experimental groups showing the equality of variances in control and experimental groups

\begin{tabular}{|c|c|c|c|c|c|c|c|c|}
\hline & \multirow[t]{2}{*}{ Group } & \multirow[t]{2}{*}{$\mathbf{N}$} & \multirow[t]{2}{*}{ Mean \pm SD } & \multicolumn{2}{|c|}{$\begin{array}{c}\text { Levene's test } \\
\text { for equality of } \\
\text { variances }\end{array}$} & \multicolumn{3}{|c|}{ t-test for equality of means } \\
\hline & & & & $\mathbf{F}$ & Sig. & $\mathbf{t}$ & df & Sig. \\
\hline \multirow[t]{2}{*}{ TOEFL placement test } & Control & 54 & $25.85 \pm 8.16$ & 0.105 & 0.747 & 1.292 & 109 & 0.199 \\
\hline & Experimental & 57 & $23.82 \pm 8.36$ & & & & & \\
\hline
\end{tabular}

A t-test $(p>0.05)$ was used for comparing the means of the reading passages scores of control and experimental groups. But first the equality of score variances was achieved through Leven's Test. The result of the test as it is demonstrated in Table 4. 4 shows significance of 0.82 which exceeds 0.05 and confirms the existence of equal variances in order to lead us to the next step which is comparing the means.

Analysis of the means of the control group (58.90) and of the experimental group (52.85) shows no significant difference between control and experimental group at the $0.05 \mathrm{lev}$ el of significance $(F=0.055, p=0.815, d f=109)$. This indicates that the experimental group did not do better than control group in its reading performance. (Table 5)

As a result the null hypothesis of this study "Computer integration has no effect on the students' reading comprehension." Is not rejected and the hypothesis of the study which postulated no significant change in reading scores of students reading on computer screen with the help of diverse online and offline resources is accepted. Figure 2 demonstrates this finding more clearl .

Overall, the analysis of the quantitative data indicated that learners who had access to reading supports on computer screen did not achieve significantly higher scores than their counterparts in the traditional reading classes.

\section{Results of the Background Questionnaires}

\section{Results of background questionnaire (Questionnaire A)}

In the background questionnaire students gave demographic information on their age and gender. Their age varied from 18 to 24, the majority were 18 and 19 years old. Eighty five percent of students were female. As it is demonstrated in Table 6, the questions in this questionnaire were divided into three groups, namely the students' access to computer, their ability in using a computer, and their expectations about the reading course.

The results of the first three questions in the first category proved that almost all of the students had their own computers $(92.45 \% \%)$, less than a third $(28.30 \%)$ reported that they had used computers only at the university or public sites, and

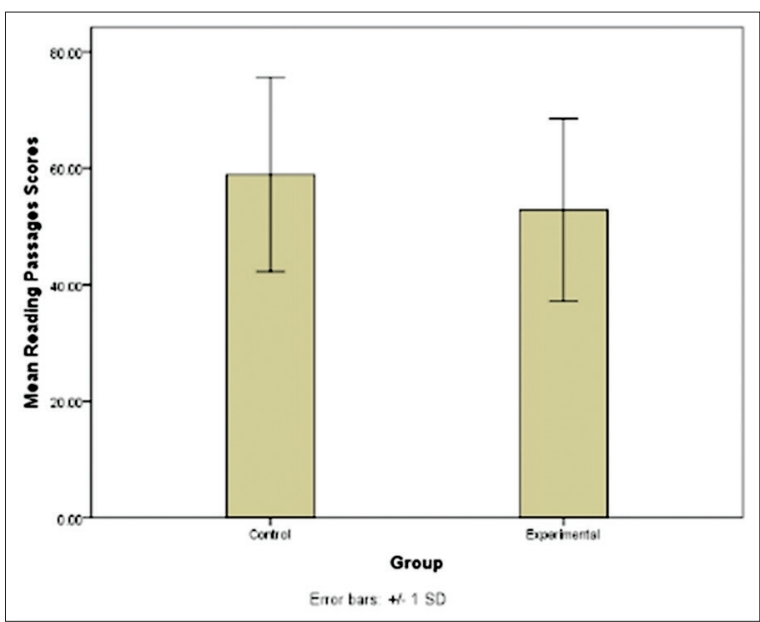

Figure 2. Mean $+1 /-1 \mathrm{SD}$ of reading passages scores showing no significant change in reading scores of experimental and control group

only a very small number (7.54\%) said that they had never used a computer before.

In the second category, the students were asked what abilities they had in using computers. A significant proportion $(73.58 \%)$ reported that they used computer to send and receive e-mails. More than two fifths (45.28\%) said they used computer to use word processor software; and more than a third $(37.73 \%)$ could surf only Persian sites, while a small minority (13.20\%) could surf only English sites. A very large majority $(84.90 \%)$ reported that they could surf both Persian and English sites.

In the third category, the results of the questionnaire indicated that all the students thought that they would do well in a computer-assisted reading course. A very large majority $(84.90 \%)$ said they were sure they could learn the skills they were taught and the same proportion $(81.13 \%)$ reported that they were confident they could understand the basic concepts taught in this course. a significant proportion (71.69\%) was confident they could do well on the assignments and tests. Regarding the difficult materials, a large proportion $(69.81 \%)$ of students was certain they could understand the most difficult material in the computer-assisted reading 
Table 4. Overall description of 10 reading passages scores

\begin{tabular}{|c|c|c|c|c|c|}
\hline & Group & $N$ & Mean \pm SD & Minimum & Maximum \\
\hline \multirow[t]{3}{*}{ TOEFL placement test } & Control & 54 & $25.85 \pm 8.16$ & 10 & 40 \\
\hline & Experimental & 57 & $23.82 \pm 8.36$ & 10 & 40 \\
\hline & Total & 111 & $24.81 \pm 8.29$ & 10 & 40 \\
\hline \multirow[t]{3}{*}{ Reading passages scores } & Control & 54 & $58.90 \pm 16.63$ & 20.70 & 88.00 \\
\hline & Experimental & 57 & $52.85 \pm 15.65$ & 21.50 & 77.90 \\
\hline & Total & 111 & $55.79 \pm 16.35$ & 20.70 & 88.00 \\
\hline \multirow[t]{3}{*}{$\mathrm{T} 1$} & Control & 54 & $66.22 \pm 19.26$ & 10.00 & 100.00 \\
\hline & Experimental & 57 & $65.11 \pm 20.36$ & 21.00 & 94.00 \\
\hline & Total & 111 & $65.65 \pm 19.75$ & 10.00 & 100.00 \\
\hline \multirow[t]{3}{*}{$\mathrm{T} 2$} & Control & 54 & $45.81 \pm 21.28$ & 0.00 & 91.00 \\
\hline & Experimental & 57 & $41.65 \pm 15.57$ & 13.00 & 77.00 \\
\hline & Total & 111 & $43.68 \pm 18.60$ & 0.00 & 91.00 \\
\hline \multirow[t]{3}{*}{$\mathrm{T} 3$} & Control & 54 & $55.04 \pm 19.03$ & 16.00 & 100.00 \\
\hline & Experimental & 57 & $51.53 \pm 20.48$ & 11.00 & 88.00 \\
\hline & Total & 111 & $53.23 \pm 19.77$ & 11.00 & 100.00 \\
\hline \multirow[t]{3}{*}{$\mathrm{T} 4$} & Control & 54 & $56.24 \pm 22.82$ & 8.00 & 100.00 \\
\hline & Experimental & 57 & $43.40 \pm 22.75$ & 0.00 & 91.00 \\
\hline & Total & 111 & $49.65 \pm 23.58$ & 0.00 & 100.00 \\
\hline \multirow[t]{3}{*}{$\mathrm{T} 5$} & Control & 54 & $42.87 \pm 25.26$ & 0.00 & 88.00 \\
\hline & Experimental & 57 & $37.93 \pm 22.12$ & 5.00 & 77.00 \\
\hline & Total & 111 & $40.33 \pm 23.72$ & 0.00 & 88.00 \\
\hline \multirow[t]{3}{*}{ T6 } & Control & 54 & $50.80 \pm 27.70$ & 0.00 & 95.00 \\
\hline & Experimental & 57 & $40.58 \pm 25.37$ & 0.00 & 95.00 \\
\hline & Total & 111 & $45.55 \pm 26.90$ & 0.00 & 95.00 \\
\hline \multirow[t]{3}{*}{$\mathrm{T} 7$} & Control & 54 & $46.43 \pm 28.34$ & 0.00 & 94.00 \\
\hline & Experimental & 57 & $43.51 \pm 24.56$ & 0.00 & 100.00 \\
\hline & Total & 111 & $44.93 \pm 26.39$ & 0.00 & 100.00 \\
\hline \multirow[t]{3}{*}{ T8 } & Control & 54 & $67.30 \pm 22.13$ & 18.00 & 100.00 \\
\hline & Experimental & 57 & $58.00 \pm 27.52$ & 0.00 & 100.00 \\
\hline & Total & 111 & $62.52 \pm 25.36$ & 0.00 & 100.00 \\
\hline \multirow[t]{3}{*}{ T9 } & Control & 54 & $84.57 \pm 13.49$ & 33.00 & 100.00 \\
\hline & Experimental & 57 & $81.07 \pm 19.38$ & 31.00 & 100.00 \\
\hline & Total & 111 & $82.77 \pm 16.80$ & 31.00 & 100.00 \\
\hline \multirow[t]{3}{*}{$\mathrm{T} 10$} & Control & 54 & $73.69 \pm 15.30$ & 18.00 & 100.00 \\
\hline & Experimental & 57 & $65.70 \pm 17.63$ & 25.00 & 100.00 \\
\hline & Total & 111 & $69.59 \pm 16.94$ & 18.00 & 100.00 \\
\hline
\end{tabular}

course. Similarly, a large proportion $(69.81 \%)$ believed that they would receive an excellent grade in this course.

\section{Results of Attitude Questionnaires}

After the experimental groups completed ten sessions of computer-assisted reading comprehension, they were asked to complete an attitude questionnaire (Appendix B). There were 25 statements in the questionnaire on the effectiveness of the computer-assisted reading course. The statements in-cluded four themes of investigation: 1) what students thought of computers as learning tools, 2) what they thought of com- puter as a component of their EFL course, 3) the ease or difficulty of using computer throughout the reading course, 4) the likelihood of their future use of the computer. The participants were required to express their thoughts on a 5-point Likert Scale in following terms: 1 (strongly agreed/SD), 2 (agreed/A). 3 (no idea/NI), 4 (disagreed/D), 5 (strongly disagreed/SD).

\section{Results of attitude questionnaire (Questionnaire B)}

Table 7 demonstrates students' ideas on the above-mentioned themes. 
Table 5. Results of independent t-test for both groups

\begin{tabular}{|c|c|c|c|c|c|c|c|c|}
\hline & \multirow[t]{2}{*}{ Group } & \multirow[t]{2}{*}{$N$} & \multirow[t]{2}{*}{ Mean \pm SD } & \multicolumn{2}{|c|}{$\begin{array}{l}\text { Levene's test } \\
\text { for equality of } \\
\text { variances }\end{array}$} & \multicolumn{3}{|c|}{$\begin{array}{c}\text { t-test for equality of } \\
\text { means }\end{array}$} \\
\hline & & & & $\mathbf{F}$ & Sig. & t & df & Sig. \\
\hline \multirow[t]{2}{*}{ Reading passages scores } & Control & 54 & $58.90 \pm 16.63$ & 0.055 & 0.815 & 1.974 & 109 & 0.051 \\
\hline & Experimental & 57 & $52.85 \pm 15.65$ & & & & & \\
\hline
\end{tabular}

Table 6. Percentages of background questionnaire

\begin{tabular}{lc}
\hline Background questionnaire: Questionnaire A (percentages) & Yes (\%) \\
Age: & No (\%) \\
Gender: Male------ Female------ & 92.45 \\
\hline Access to computer: & 28.30 \\
I have my own computer at home & 7.54 \\
I use the computer only at the university or public sites & 7.54 \\
I have never used a computer before & 71.59 \\
Your ability in using a computer: & 73.58 \\
Before this course I could: & 45.28 \\
Send and receive e-mails & 37.73 \\
Use word processor software & 13.20 \\
Surf the web (Persian sites only) & 84.90 \\
Surf the web (English sites only) & 52.45 \\
Surf the web (Persian and English sites only) & 81.13 \\
Your expectations about this reading comprehension course: & 84.71 \\
I am confident I can understand the basic concepts taught in this course & 62.26 \\
I am sure I can master the skills being taught in this class & 86.79 \\
Considering the difficulty of this course and my skills, I think I will do well in this class & 92.45 \\
I am confident I can do an excellent job on the assignments and tests in this course & 71.69 \\
I am certain I can understand the most difficult material in the readings in this course & 69.81 \\
I believe I will receive an excellent grade in this class & 69.81 \\
\hline
\end{tabular}

\section{The computer as a learning tool}

As Table 7 illustrates a significant proportion of the students liked the computer as a learning tool $(\mathrm{A}+\mathrm{SA}=69.99 \%)$ and about $93.33 \%(\mathrm{~A}+\mathrm{SA})$ agreed that being able to use the computer was a valuable skill. Considering different skills that computers can provide learners, a significan proportion (68.33\%) found computers as useful tools. In addition, a very large majority $(\mathrm{A}+\mathrm{SA}=90 \%)$ agreed that computer reading texts helped them in reading English websites. However, almost a half $(\mathrm{D}+\mathrm{SD}=49.99 \%)$ did not believe that computers can substitute teachers and reported that they needed teacher's help. However, more than half $(\mathrm{A}+\mathrm{SA}=42.85)$ reported they could work solo without relying on teacher. Similarly, a large majority of participants $(A+S A=94.99)$ indicated that the teacher's explanation on the use of program was helpful.

A closer look at Table 7 shows that the experimental group is generally certain about either computers as an educational tool or their own abilities as EFL students. However, the proportions of the subjects who agreed or strongly agreed with the four themes of the questionnaire are gener- ally above the medium proportion. While the number of the subjects who look reluctant are below the medium proportion. These results are indicative of the fact that the computer-assisted reading course can prove useful to participants as soon as they reach certainty about computer capabilities as a learning tool. As, in this study, it is evident that a small minority raised doubts about such an innovation in language teaching and learning.

\section{Computer as a component of EFL course}

Approximately a very large majority $(\mathrm{A}+\mathrm{SA}=79.99 \%)$ agreed that the pictures accompanying words were helpful in understanding the readings. Likewise, a very large majority $(\mathrm{A}+\mathrm{SA}=88.33 \%)$ reported that use of computers in this course made it more interesting. Students also expected to get a better grade in a reading comprehension course if using the computer becomes part of it $(\mathrm{A}+\mathrm{SA}=$ $59.99 \%)$. Though less than a quarter $(23.33 \%)$ expressed doubts about the idea. In addition, a significant proportion $(\mathrm{A}+\mathrm{SA}=68.33 \%)$ believed that the reading passages were interesting. 
Table 7. Attitude questionnaire (percentage)

\begin{tabular}{|c|c|c|c|c|c|c|}
\hline & 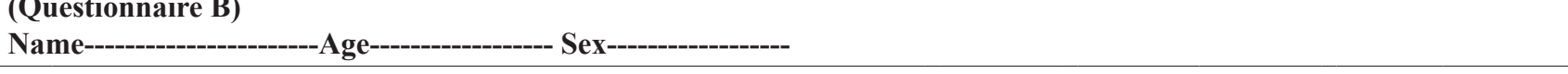 \\
\hline & & SA (\%) & $A(\%)$ & NI (\%) & $\mathbf{D}(\%)$ & SD (\%) \\
\hline 1 & Being able to use the computer is a valuable skill & 40 & 53.33 & 6.66 & 0 & 0 \\
\hline 2 & I learned more computer skills because of attending this course & 25 & 43.33 & 25 & 5 & 1.66 \\
\hline 3 & $\begin{array}{l}\text { I think the computer reading texts can help me in reading English } \\
\text { websites }\end{array}$ & 40 & 50 & 6.66 & 3.33 & 0 \\
\hline 4 & In general I learned more English because of using the computer & 13.33 & 53.33 & 26.66 & 5 & 1.66 \\
\hline 5 & The information on the computer has helped me learn English grammar & 15 & 46.66 & 26.66 & 5 & 1.66 \\
\hline 6 & $\begin{array}{l}\text { In comparison with the traditional method (paper-based reading } \\
\text { comprehension) the program helped me learn vocabulary better }\end{array}$ & 33.33 & 36.66 & 18.33 & 11.66 & 0 \\
\hline 7 & $\begin{array}{l}\text { I can remember many of the new words in the reading because of the } \\
\text { pictures accompanying them }\end{array}$ & 31.66 & 43.33 & 23.33 & 1.66 & 0 \\
\hline 8 & $\begin{array}{l}\text { Reading the English information on the computer is easier than reading } \\
\text { from textbook }\end{array}$ & 21.66 & 43.33 & 15 & 20 & 0 \\
\hline 9 & I liked using the computer in this course & 41.66 & 28.33 & 25 & 5 & 0 \\
\hline 10 & Use of computers in this course made it more interesting & 43.33 & 45 & 8.33 & 3.33 & 0 \\
\hline 11 & $\begin{array}{l}\text { I talked to my classmates more because of the use of computer in this } \\
\text { course }\end{array}$ & 16.66 & 43.33 & 28.33 & 11.66 & 0 \\
\hline 12 & $\begin{array}{l}\text { I expect to get a better grade in a reading comprehension course if } \\
\text { using the computer becomes part of it }\end{array}$ & 31.66 & 28.33 & 23.33 & 5 & 1.66 \\
\hline 13 & The reading passages were interesting & 38.33 & 48.33 & 8.33 & 1.66 & 3.33 \\
\hline 14 & The words in bold type helped me understand the reading better & 31.66 & 50 & 16.66 & 1.66 & 0 \\
\hline 15 & $\begin{array}{l}\text { The pictures accompanying words were helpful in understanding the } \\
\text { reading }\end{array}$ & 36.66 & 43.33 & 21.66 & 0 & 0 \\
\hline 16 & The reading comprehension questions were too easy for me & 25 & 43.33 & 18.33 & 13.33 & 0 \\
\hline 17 & It was easy to work on computer & 33.33 & 41.66 & 21.66 & 3.33 & 0 \\
\hline 18 & I felt confident using the computer to find the information I need & 28.33 & 46.66 & 21.66 & 3.33 & 0 \\
\hline 19 & The teacher's explanation on the use of program was helpful & 61.66 & 33.33 & 5 & 0 & 0 \\
\hline 20 & $\begin{array}{l}\text { I was able to complete reading along without asking for help from the } \\
\text { teacher }\end{array}$ & 18.33 & 36.66 & 13.33 & 26.66 & 5 \\
\hline 21 & I didn't need my teacher's help because of the use of computer & 5 & 30 & 16.66 & 43.33 & 6.66 \\
\hline 22 & $\begin{array}{l}\text { I could finish reading the comprehension passages in this program } \\
\text { faster than paper-based reading comprehension }\end{array}$ & 38.33 & 33.33 & 16.66 & 10 & 1.66 \\
\hline 23 & $\begin{array}{l}\text { I would like to take another course that includes the use of the } \\
\text { computers }\end{array}$ & 28.33 & 38.33 & 25 & 5 & 3.33 \\
\hline 24 & $\begin{array}{l}\text { I prefer to use this kind of reading program even after my assignment } \\
\text { is finished }\end{array}$ & 30 & 45 & 18.33 & 5 & 1.66 \\
\hline 25 & The use of computer is unnecessary in this course & 6.66 & 16.66 & 36.66 & 25 & 15 \\
\hline
\end{tabular}

A very large majority $(\mathrm{A}+\mathrm{SA}=81.66 \%)$ believed the words in bold type helped them understand the reading better and two fifths $(\mathrm{D}+\mathrm{SD}=40 \%)$ disagreed that it was unnecessary to use computers in a reading course, while only $23.32 \%(\mathrm{~A}+\mathrm{SA})$ agreed with the idea. A significant proportion $(\mathrm{A}+\mathrm{SA}=68.33 \%)$ confirmed that the reading comprehension questions were too easy for them. A significant proportion $(\mathrm{A}+\mathrm{SA}=61.66 \%)$ reported that the information on the computer had helped them learn English grammar. Similarly, A significant proportion $(A+S A=69.99 \%)$ held that in comparison with the traditional method (paper-based reading comprehension) the program had helped them learn vocabulary better.

\section{Ease/Difficulty of the task}

As is shown, a significant proportion of the experimental group thought that it was easy to work on computer (A $+\mathrm{SA}=74.99 \%$ ) and the same proportion felt confident using the computer to find the information they needed $(\mathrm{A}+\mathrm{SA}=$ 74.99\%). A significant majority agreed that they could finish reading the comprehension passages in this program faster than paper-based reading comprehension (A $+\mathrm{SA}=71.66 \%$ ).

These results are not surprising since a small majority of students had already reported that they were familiar with computer skills in the background questionnaire. 


\section{Likelihood of future use}

A good indication of the high success rate of this program was the students' significant proportion to take another course that includes the use of computers $(A+S A=66.66 \%)$, while exactly a quarter (25\%) expressed no idea. Similarly, a very large majority $(\mathrm{A}+\mathrm{SA}=75 \%)$ reported that they preferred to use this kind of reading program even after their assignment was finished and a small minority (18.33\%) expressed no idea.

The final statement of the questionnaire, "The use of computer is unnecessary in this course." was added to make sure the participants were not answering the questions mindlessly. Two-fifths of participants $(\mathrm{D}+\mathrm{SD}=40 \%)$ consented to the use of computer, whereas more than a third $(36.66 \%)$ felt doubtful.

The results of this study indicated that participants' reading comprehension showed no improvement as a result of computer-assisted instruction. The analysis of the data detected no significant differences between the control and the treatment condition. In other words, Computer-assisted reading could not help participants score higher than those who were subjected to traditional reading program.

The overall findings of this study do not support the interactive effect of computer on students' reading comprehension. The low percentages of the attitude questionnaire for the learners also support their failure to benefit from computers. The findings also support the conclusion that computers may enhance students' motivation and interest towards learning but they do not enhance comprehension. This seems to contradict the results established by some researchers who support the inclusion of computer in the teaching of reading skill. I will raise the issue for discussion in the next part.

\section{DISCUSSION}

In this study, the first research question concerned whether there is any statistically significant difference between the reading comprehension of students reading passages on the computer equipped with diverse online resources and that of those reading the same passages on paper in traditional way by the help of teacher. Null and alternative hypotheses derived from the research question were analyzed. Based on the analysis presented in chapter four, the null hypothesis was not rejected. Analysis of mean scores of control and experimental groups showed no significant difference between the means. As a result, the analysis of the means of the reading passages scores showed no significant difference between control and experimental group at the 0.05 level of significance $(\mathrm{F}=0.055, \mathrm{p}=0.815, \mathrm{df}=109)$

This study found no positive correlations between computer-assisted reading comprehension and traditional reading comprehension. These results are consistent with the findings of many of the researchers in the field especially Kerr \& Symons (2006), Wästlund (2007), Ackerman \& Lauterman (2012), Mangen et al. (2013), Noyes and Garland (1982), Sakar and Ercetin (2005), Wastlund, Reinikka, Norlander, \& Archer (2005), Uso and Ruiz (2009), Rice (1994), Kleimann (1987), and Ridder (2000) who found no significant difference between the two presentation mode (paper vs. computer). In addition, Ferlazzo L. (2016), Daniel \& Willingham (2012), Hasher \& Zacks, (1979), Rasmusson (2015) and Zucker, et al. (2009) sound more like apologists when they concluded that "the death of paper books may be greatly exaggerated" and that reading from a screen reduces students' comprehension.

These findings cause confusion, especially when they are hotly contrasted by some researchers, namely, Wright et al. (2013), Dillon (1992), Nelson (1987), Yanguas (2009), Chun and Plass (1996b), Lomika (1998), Rahimi and Behjat (2011), Sotoudehnama \& Dehghan (2013), Khoshkar and Nimvari (2014), who maintained that computer-aided reading enhanced reading comprehension. However, the findings of the present study contradict their findings. Statistical analysis of data proved no significant change between students in control and experimental groups in Iranian context. The results indicated that computer supports did not influence learners' reading comprehension, but improved their satisfaction and interest.

Alternatively, Lauterman and Ackerman (2014) stated that reading performance is a matter of preference and concluded that readers can overcome screen inferiority if they prefer to choose one presentation mode over another. Some other researchers like Knight (1994), Davis \& Lyman-Hager (1997), Ariew \& Ercetin (2004), and some others found contradictory results. These authors had different views, for example, one view can be since multiple forms of annotations offer concurrent presentations for multimedia information, because of the attention lapses between different kinds of information, deleterious effects result (Ariew \& Ercetin, 2004), the effect that is controlled in some studies by presenting only one type of multimedia annotation, i.e. picture annotations accompanied with verbal input.

Others were influenced by Mayer (2002)'s cognitive theory of multimedia learning (cited in Sakar \& Ercetin, 2005, p. 36), a later version of generative theory of multimedia learning (Mayer, 1997), which postulates that multimedia information may have deleterious effects when a single channel according to Pavio (1989 \& 1971, cited in Chun \& Plass, 1997, p. 65)'s dual channels assumption is overcharged. This seems to be reasonable in case of video annotations, because in such annotations the visual channel is overcharged with verbal information received from videos, which result in the redundancy effect caused by simultaneous presenting of text and videos.

Eventually, proficiency level of the learners can be the reason of these mixed results. For example, by considering this variable, some researchers have provided evidence that annotations are more advantageous to low proficient learners (Chun, 2001; Knight, 1994). Relying more on annotations to understand the text in order to make up for their linguistic weaknesses are the reasons Chun and Plass (1997) provide to support their claim.

\section{The Second Research Question: Learners'Attitudes And Perceptions}

As it was mentioned above, Kretzschmar et al. (2013) concluded that doubts towards electronic reading may send back 
a general cultural attitude towards reading on screen rather than quantifiable mental effort during reading. In addition, Ackerman and Lauterman (2012) concluded that the problem with screen reading is more psychological than technological. Their study also argues that medium preferences matter, since those who studied on their preferred medium showed both less overconfiden e and got better test scores. These studies imply that language learning is greatly affected by learners' attitudes and perceptions. Moreover, Reinders (2000) contends that educating students to become more autonomous is one thing, how students view this is another. It is greatly influenced by how they view language, language education. Learners' perceptions have an impact on their behavior and it is therefore important to understand them. Cotterall (1999, as cited in McDonough, 1999) stated that the way we see the world and our perceptions of our world form the basis of our personal decisions. This argument implies that it is unnecessary for these kinds of evidence to be true for them to have significant results for our further progress. (p.9).

Likewise, the majority of researchers agree that the level of effectiveness of technology enhanced learning programs largely depends on the way in which the technology is integrated into the curriculum and how it is viewed by students, teachers, and school administrators.

... Technology is only a tool; it allows us to develop dialogue and interaction, but is a means, not an end in and of itself. Tech-based global education has the capacity to improve critical thinking and cultural pluralism but requires far more than just fancy technology; it requires careful, thoughtful curriculum development, and the support of organizations whose goal is to build authentic global communities online. (Klein, 2010, p. 86)

Similarly, Nowak and Rauh (2005) found that while media features or characteristics must be considered when selecting technology, "social norms and rules influence how media are, and should be used" (Nowak \& Rauh, 2005, p. 3).

Benson and Lor (1999) also claimed that beliefs about learning are based on conceptions. What is important here is that there is a difference between conceptions and beliefs, where conceptions are what learners think the object and processes of learning are and beliefs are what the learner holds to be true about these objects and processes. Our conceptions limit our beliefs, which in turn determine our approach. Beliefs about learning and language learning are complex and made up of different elements. Although it is unclear how learners' conceptions and beliefs influence behaviour, it is clear that they do, and that therefore, they need to be addressed if any changes in behaviour are to be expected. (Reinders, 2000)

Furthermore, it is critically important for students and educators to use computers in their teaching and learning and become familiar with the new environment and change their educational approaches (Zhang \& Espinosa, 1997). Research shows that application of technology improves attitudes toward computers (Delcourt \& Kinzie, 1993; Birisci, Metin, \& Karakas, 2009; Teo, 2008). Therefore, the most critical element that influences educators' attitudes toward utilizing technology in the classroom could be building more positive attitudes. In the event that educators' attitudes toward innovation are negative, they would not have any desire to utilize computers in the teaching and learning process. Particularly, Kersaint et. al., (2003) have demonstrated that the useful application of educational technology largely relies on the attitudes of instructors, who in the end decide how they are utilized in the classroom. Bullock (2004) discovered that educators' attitudes have a vital impact on the embrace of technology for teaching and learning. Apart from general attitudes towards the language (including countries and cultures where the language is used as a first language), the specific learning situation (environment, teacher, materials) can motivate or impede the learner. It is often forgotten that not only the content of the learning materials is important, but also their mode of presentation is important. This concerns the type of language, the level of difficult , design and layout of the task and the medium through which it is presented (Lenders, 2008).

The usefulness of any new method used in foreign language teaching is ultimately dependent on whether it is accepted by the learners. Therefore, the researcher set the learner attitudes and beliefs as the secondary purpose of exploration in this study. The analysis of this factor included two questionnaires: A background questionnaire (Appendix A) which was given to the participants before the treatment and an attitude questionnaire (Appendix B) which was filled by the same participants just after the treatment

It was stated that the experimental group was not able to thoroughly utilize the computer resources so as to increase their comprehension of the reading passages. Although the result of this study was to some extent unexpected and in contradiction to other studies done in this area, and there was no doubt about the efficacy of computer technology, There were some factors and theoretical reasons in the literature for this phenomenon.

One of the factors may have been the novelty of this method in the instructional environment of that college and the fact that the EFL students needed more time and opportunity to accommodate themselves to computer-based instruction.

Other reasons may be lack of motivation and the limited time of the treatment. Students could not likely create a relationship between computer and passages. Individual differences may be another reason for their function. Another possible reason may be partially attributable to the low proficiency level of the students

Warschauer and Matuchniak (2010) reported that Lower-achieving students are more likely to use technology for socially driven activities such as chatting or playing games with friends using social media, following pop-ups, or surfing through links of celebrities and sports fi ures, whereas high-achieving students are not only more likely to use technology for interest-driven activities such as researching topics or collaborating online to create new media, but are also more likely to have adult guidance in its use.

Ghenghesh (2015) reported that there is a significant but moderate positive relation between the students' proficiency 
in English and their overall academic success. Specificall, the higher the English proficiency of students on entry to the university, the better they performed in their degree area courses as well as in their English levels. Similarly, Rahimi and Yadollahi (2011) reported that computer anxiety and achievement in English had a contrary relationship and high achievers exceeded low achievers in using computers.

Moreover, Computer possession correlated highly with students' success in English, and except gender, achievement in English, PC time, and computer possession were determinants of computer anxiety. Conti-Ramsden et al. (2010) contended that Language is important to computer because using computer involves language, including reading, sending and receiving messages, and following hyperlinks, etc. Therefore, while using computers.,low proficiency students are likely to experience anxiety. Since English is the computer language (Albirini, 2006), and since computer users are in dire need of English language to seek what they need (Navdal, 2007), it is reasonable that more English proficient students suffer less anxiety while working with computers.

In addition, Mashhadi et al. (2006) investigated factors that affected university professors while working with computers in Iran. They discovered that there was a strong relationship between attitudes toward computer and computer use, English proficienc, and computer skills. Similar fin ings were reported by Yaghoubi and Shamsai (2004). Likewise, Movahed Mohammadi and Javani (2002) and Karimi and Mokhtarnia's (2004) reported a strong relationship between attitudes and English proficienc , computer expertise, and frequency of computer use.

In general, students' low English proficiency or their difficulties with the English skills have great impacts on their academic performance. Those who are more proficient in the English skills are indicated having less challenges in their studies; and the lecturers should adjust the standards and grading criteria to help the learners to be successful academically (Andrade, 2009: 19). There is a possibility that the learners are unable to obtain the certain level of computer literacy because they have difficulties with English skills as well as English knowledge. This is consistent with Suarez-Orozco et al (2008) and Carhill et al (2008:1160) who stated that English language proficiency has vital role in predicting academic achievement for EFL learners.

Lesser and Winsor (2009), as cited in Veerasammy and Shillabeer (2014), reported that students with limited English knowledge try hard in understanding the concepts and may not be able to complete their assignments. Moreover, simplifying both the language and the content of English language in order to help the students to understand their field of study will result in decreasing the students' ability to function in the particular domain (Tan \& Lan, 2011 as cited in Veerasammy and Shillabeer, 2014:19).

It is important to realize that the students who do well in English, both in the level of knowledge and proficienc , will be able to handle problems while working with computer. The English language is needed to improve the students' ability in using computer for EFL students. Low English proficiency holds low proficien EFL learners back, makes them uncertain and lose their confidence, whereas proficient EFL learners will find it easier to comprehend the language of computer, to use the computer instructions, vocabulary, syntax, and symbols, and to identify the problems of their explorations on the screen.

Computer has been claimed to be facilitative by providing a basis for developing reading comprehension and coping with ambiguities and to be preventative by providing the synonyms and antonyms for unknown words and expressions potential of causing anxiety and miscomprehension.

\section{CONCLUSION}

Lomika (1998) suggested that: research has examined only the superficial aspects of computer-assisted reading comprehension. However, some promising research in the field is already showing some progress. The findings of such research are encouraging and should be of great benefit to teachers who prefer to use computers in their classrooms. Modern language teachers are advised to consider what computer industry offers for their classrooms, and should consequently motivate their students to use them efficien ly and cautiously after necessary training. Using technology does not necessarily mean language teachers should prohibit traditional print-based reading, but instead, they should seek their students learning preferences and needs and take subsequent measures accordingly. As it was mentioned before, EFL language teachers are recommended to take into account all factors including environmental factors, cultural factors, socioeconomic factors, age, gender, linguistic background, accessibility, acceptability, and learning preferences and styles before incorporating computer technology. Otherwise, blindfold consent to use technology in any EFL context without considering the above-mentioned factors would lead to fallacies.

Moreover, methods and tools should not be used mechanically but should be context specific. It would be a mistake to believe that some developing countries like Iran can mirror English-dominant as well as technology-dominant contexts such as the US, Japan, Chile and Singapore. Developing countries need to develop more technological capability and greater flexibility to facilitate the first use of new technology in the domestic context. As Selwyn (2013).stated, "digital technologies are shaped by the social contexts in which they are implemented" (p.21) and by this, he suggests that we need to consider the influence of issues such as language and religion. Selwyn (2013).also argues that educational technology needs to be viewed in the broader political, economic, social, cultural and historical contexts of the countries in which it is being implemented. Furthermore, Osin (1998) took context into account when he stated that "he tried to avoid the usual pitfall of many transfer-of-technology projects, which is to "copy" in a developing country a project that was successful in a developed country." Osin also asserts:

"In developing countries, with large segments of the population living at extreme levels of poverty, the first question that must be asked is whether it is reasonable to invest money in technology for the educational system, instead of using the 
same money to improve the living conditions of those in dire need. I believe that these interests are not contradictory and that the only way to reach a long-term solution for the economic problems of the population is to raise the educational level, particularly for the low socio-economic groups." (p.2)

Further, Osin observes that competitiveness in international markets relies more on the educational level of human resources than on raw materials, and automation of industrial and commercial processes has made personnel migrate towards more intellectually challenging tasks. Therefore, the present educational system has the responsibility to provide the graduates at the levels needed for such tasks.

Nevertheless, developing countries are more likely to derive greater benefit from computer technology in education if the so-called "digital natives" of these countries were trained to use their digital literacy for the benefit of their education rather than for fun and communication. Prensky(2001) contends that our students are all native speakers of the digital language of computers, video games and the Internet and his argument is based on the assumption that the "thinking patterns" of these speakers have changed. However, Prensky is talking about the US and similar developed countries and he does not generalize about any contexts in the world. Following such trends of thoughts which is context-specific by no means guarantees the desired outcome in developing countries in which qualities such as digital nativeness and change in thinking-patterns cannot commonly be ascribed to most EFL learners. Technology alone cannot improve the delivery of knowledge; a new computer cannot make a teacher better. Nor can it provide a magic formula to improve learning; a new pencil does not make a child better at writing essays (Cuban, 1986, Cuban, 2001). Technology itself "does not bring about reform, but instead tends to amplify extant beliefs and practices" (Warschaucer, 2011, p. 115, cited in Reinders and Hubbard, (2012). Once education is improved, we can expect technology to accelerate the process. Jobs (as cited in Wolf, 1996) once said in an interview that "what's wrong with education cannot be fixed with technology." Throwing technology at the problem of education today based on the highly emotive and often ambiguous terms such as "digital education revolution" and "digital natives" does little to address the underlying social, economic pedagogical challenges that instead deserve the full attention of education reformers (Gee, 2003, 2004; Gee and Hayes, 2011; Selwyn, 2011a, 2011b). The slow pace of technological revolution and breakthroughs in some developing countries makes the slow pace of EFL learners' thinking pattern. Educational systems are resistant to change, and a transformation that purports to accelerate the solution of the problems requires the support of educational technology (Osin, 1998). However, this technology should supplement not supplant teachers (Balajthy, 1996b) or more traditional forms of reading instruction (D'Silva, 2006, p.15).

Technology has been reported to have slowed down the progress of students in schools and colleges. Besides, a mountain of research has demonstrated that most educators still resist changing the ways they teach and incorporating technology into their context. Computers can be an expensive waste of time unless teachers integrate them appropri- ately to meet students' needs. Informed, flexible, dedicated teachers remain the key to effective instruction (Balajthy, 1999). Moreover, additional research is needed to determine whether technology and online learning are improving learning outcomes for most EFL students. Many people argue the computer does all the work for the students, not allowing them the opportunity to digest what they have learned. Boyle (1998) argues that information technology "may actually be making us stupid." (p. 618). He argues that the computer takes more of the thinking process out of students. Furthermore, teachers and parents alike have expressed concerns about digital distractions, "ways in which unequal access to and use of technology might widen achievement gaps."

Eventually, Beniger (1989) and Postman (1995, as cited in Brown, 2011) warn against the overuse or misuse of technology:

"We proceed under the assumption that information is our friend, believing that cultures may suffer grievously from a lack of information, which, of course, they do. It is only now beginning to be understood that cultures may also suffer grievously from information glut, information without meaning, information without control mechanisms." (Beniger, 1989, p. 70).

\section{REFERENCES}

Ackerman, R., \& Lauterman, T. (2012). Taking reading comprehension exams on screen or on paper? A metacognitive analysis of learning texts under time pressure. Computers in human behavior, 28(5), 1816-1828.

Adamovic, M. (2009). Test document readability calculator. Retrieved from the Online Utility. org website.: http:// www.online-utility.org/English/readability_test_and_ improve.jsp

Afflerbach, P., \& Cho, B. (2009). Identifying and describing constructively responsive comprehension strategies in new and traditional forms of reading. In S. E. Israel \& G. G. Duffy (Eds.), Handbook of research on reading comprehension (pp. 69- 90). New York: Routledge.

Akyel, A., \& Erçetin, G. (2009). Hypermedia reading strategies employed by advanced learners of English. System, 37(1), 136-152.

Albirini, A. (2006). Teachers' attitudes toward information and communication technologies: The case of Syrian EFL teachers. Computers \& Education, 47(4), 373-398. http://dx.doi.org/10.1016/j.compedu.2004.10.013

Alemi, M., \& Ebadi, S. (2010). The effects of pre-reading activities on ESP reading comprehension. Journal of Language Teaching and Research, 1(5), 569-577

Anderson-Inman, L., \& Horney, M. (1997). Electronic books for secondary students. Journal of Adolescent \& Adult Literacy, 40, 486-491.

Andrade, M.S. 2009. The Effects of English Language Proficiency on Adjustment to University Life. International Multilingual Research Journal, 3: 16- 34.

Ariew, R., \& Erçetin, G. (2004). Exploring the potential of hypermedia annotations for second language reading. Computer Assisted Language Learning Journal, 17, 237-259. 
Balajthy, E. (1999). Using computers for intervention and remediation of severely reading-impaired children in a university literacy clinic. Presented at International Reading Association Convention, Microcomputers in Reading Special Interest Group, San Diego, CA.

Beniger, J. R. (1989, January). The evolution of control. In Computers in the human context: Information technology, productivity, and people (pp. 48-70). MIT Press.

Benson, P., \& Lor, W. (1999). Conceptions of language and language learning. System, 27(4), 459-472.

Birisci, S., Metin, M., \& Karakas, M. (2009). Prospective elementary teachers' attitudes toward computer and Internet use: A sample from Turkey. World Applied Science Journal, 6(10), pp. 1433-1440.

Boyle, F. T. (1998). IBM talking head's, and our classrooms. College English, 55 (6), pp. 618-626.

Brown, J. (2011). Does the use of technology in the classroom increase students' overall academic performance? (pp. 1-45).

Bullock, D. (2004). Moving from theory to practice: an examination of the factors that preservice teachers encounter as they attempt to gain experience teaching with technology during field placement experiences. Journal of Technology and Teacher Education, 12(2), 211-237.

Carhill, A., Suárez-Orozco, C., \& Páez, M. (2008). Explaining English language proficiency among adolescent immigrant students. American Educational Research Journal, 45(4), 1155-1179.

Carrell, P. L. (1985). Facilitating ESL reading by teaching text structure. TESOL quarterly, 727-752.

Carhill, A., Suarez-Orozco, C., Paez, M. 2008. Explaining English Language Proficiency among Adolescent Immigrant Students. American Educational Research Journal, 45 (4): 1155-1179.

Chapelle, C. A. (2002). Computer-assisted language learning. In R. Kaplan, (Ed.). Handbook of applied linguistics (pp. 499-505). Oxford: Oxford University Press.

Chun, D. M. (2001). L2 reading on the web: Strategies for accessing information in hypermedia. Computer Assisted Language Learning, 14(5), 367-403.

Chun, D.M., \& Plass, J.L. (1996b). 'Facilitating reading comprehension with multimedia.' System, 24(4), 503519.

Chun, D. M., \& Plass, J. L. (1997). Research on text comprehension in multimedia environments. Language learning \& technology, 1(1), 60-81.

Clements, D.H., \& J. Sarama. (2003). Strip mining for gold: research and policy in educational technology: a response to 'fool's gold." AACE Journal, 11 (1): 7-69.

Coiro, J. (2003). Exploring literacy on the internet: Reading comprehension on the internet: Expanding our understanding of reading comprehension to encompass new literacies. The reading teacher, 56(5), 458-464.

Conti-Ramsden, G., Durkin, K., \& Walker, A. J. (2010). Computer anxiety: A comparison of adolescents with and without a history of specific language impairment (SLI). Computers \& Education, 54(1), 136-145.

Cottrell, S. (1999). The study skills handbook. London:
Macmillan Press.

Cuban, L. (1986). Teachers and machines: The classroom use of technology since 1920. New York: Teachers College Press.

Cuban, L. (2001). Oversold and underused: Computers in the classroom. Cambridge, MA: Harvard University Press.

Daniel, D. B., \& Willingham, D. T. (2012). Electronic textbooks: why the rush? Science, 335, 1569.

Davis, J. N., \& Lyman-Hager, M. (1997). Computers and L2 reading: Student performance, student abilities. Foreign Language Annals, 30, 58-72.

Delcourt, M. A. B., \& Kinzie, M. B. (1993). Computer technologies in teacher education: The measurement of attitudes and self-efficac . Journal of Research and Development in Education, 27(1), 35-41.

De Ridder, I. (2000). Are we conditioned to follow links? Highlights in CALL materials and their impact on the reading process. Computer Assisted Language Learning, 13(2), 183-195.

Dillon, A. (1992). Reading from paper versus screens: a critical review of the empirical literature. Ergonomics, $35(10), 1297-1326$.

D'Silva, R. (2006). Reading by bits and bytes: The use of computer reading software in classrooms. English Quarterly, 38(4). Retrieved April 6, 2017 from CBCA Education database.

Educational Testing Service. (n.d.). Handbook for the TOEFL Junior Standard Test. Retrieved April 7, 2017 from http://www.ets.org/s/toefl junior/pdf/toefl junior_s dent_handbook.pdf

Ferlazzo L. (2016). Why the Death of Paper Books may be Greatly Exaggerated. Retrieved February 22, 2017 from

http://blogs.edweek.org/teachers/classroom_qa_with_larry_ ferlazzo/2016/05/response_reading_digitally_vs_reading_paper.html?cmp=eml-eb-popweek +06032016

Friedman, T. L. (2005). The world is flat: A brief history of the twenty-first century. Macmillan.

Gajria, M., Jitendra, A. K., Sood, S. \& Sacks, G. (2007). Improving comprehension of expository text in students with LD: A research synthesis. Journal of Learning Disabilities, 40, 210-225.

Gee, J. P. (2003). What video games have to teach us about learning and literacy ( $1^{\text {st }}$ ed.). New York: Macmillan.

Gee, J. P. (2004). Situated language and learning: A critique of traditional schooling. Psychology Press.

Gee, J. P., \& Hayes, E. R. (2011). Language and learning in the digital age. Routledge.

Ghenghesh, P. (2015). The Relationship Between English Language Proficiency And Academic Performance of University Students-Should Academic Institutions Really be Concerned? International Journal of Applied Linguistics and English Literature, 4(2), 91-97.

Glaubke, C. R. (2007). The effects of interactive media on preschoolers' learning: a review of the research and recommendations for the future. Oakland, CA: Children Now.

Hatch, E. M. (1978). Second language acquisition: A book of 
readings. Newbury House Pub.

Hartman, D.K., Morsink, P.M., \& Zheng, J. (2010). From print to pixels: The evolution of cognitive conceptions of reading comprehension. In E.A. Baker (Ed.), The new literacies: Multiple perspectives on research and practice (pp. 131-164). New York, NY: Guilford.

Kenny C. (2013). The false promise of classroom technology. Reading online. Retrieved February 18, 2017, from https:/www.bloomberg.com/news/articles/2013-11-11/ the-false-promise-of-classroom-technology

Karimi, A., \& Mokhtarnia, M. (2004). Barresi avamele mo'aser bar karbord fannaveri ettela'ati va ertebati (ICT) tavasot amoozeshgaran dar honarestanhaie fanni va herfeei keshavarzi: Motale'ei moredi ostane Zanjan [Exploring effective factors influencing Information and Communications Technology (ICT) use by teachers of agricultural technical schools: A case study in Zanjan]. Majalleye Oloum Keshavarzi, 58, 321-332.

Kersaint, G., Horton, B., Stohl, H., \& Garofalo, J. (2003). Technology beliefs and practices of mathematics education. Journal of Technology and Teacher Education, 11(4), 549-577.

Kerr, M. A., \& Symons, S. E. (2006). Computerized presentation of text: Effects on children's reading of informational material. Reading and Writing, 19(1), 1-19.

Khoshkar, A., \& Nimvari, A. A. E. (2014). The effect of using pictogloss on iranian EFL learners'reading comprehension ability. Modern Journal of Language Teaching Methods, 4(1), 86.

Kingsley, T. (2011). Integrating new literacy instruction to support online reading comprehension: An examination of online literacy performance in $5^{\text {th }}$ grade classrooms (Unpublished doctoral dissertation). Ball State University, Muncie, IN.

Klein, J. D. (2010). When you can't bring your classroom to the world, bring the world into your classroom. Youth Media Reporter, 486-88.

Kleinmann, Howard H. (1987). The effect of computer-assisted instruction on ESL reading achievement.The Modern Language Journal, 71(3), 267-276.

Knight, S. (1994). Dictionary: The tool of last resort in foreign language reading: A new perspective. The Modern Language Journal, 78, 285-299.

Kretzschmar, F., Pleimling, D., Hosemann, J., Füssel, S., Bornkessel-Schlesewsky, I., \& Schlesewsky, M. (2013). Subjective impressions do not mirror online reading effort: Concurrent EEG-eyetracking evidence from the reading of books and digital media. PloS one, 8(2), e56178.

Kuiper, E. J. (2007). Teaching web literacy in primary education (Doctoral dissertation, eigen beheer).

Lauterman, T., \& Ackerman, R. (2014). Overcoming screen inferiority in learning and calibration. Computers in $\mathrm{Hu}$ man Behavior, 35, 455-463.

Lenders, O. (2008). Electronic glossing-is it worth the effort? Computer Assisted Language Learning, 21(5), 457-481.

Lesser, L., \& Winsor, M. (2009). English language learners in introductory statistics: Lessons learned from an exploratory case study of two pre-service teachers. Statistics Education Research Journal, 8(2), 5-32.

Leu, D. J. (2007, May). What happened when we weren't looking? How reading comprehension as changed and what we need to do about it. Keynote research address presented at the annual meeting of the International Reading Association, Toronto, Canada.

Leu, D. J., Kinzer, C. K., Coiro, J. L., \& Cammack, D. W. (2004). Toward a theory of new literacies emerging from the Internet and other information and communication technologies. Theoretical models and processes of reading, 5(1), 1570-1613.

Locke, T., \& Andrews, R. (2004). A systematic review of the impact of ICT on literature-related literacies in English 5-16. EPPI-Centre, Social Science Research Unit, Institute of Education, University of London.

Lomicka, L. (1998). To gloss or not to gloss: An investigation of reading comprehension online. Language learning \& technology, 1(2), 41.

Mahboudi,H.R. (2010). An Anthology of Collegiate Readings. Tabriz: Forouzesh Publications.

Mangen, A., Walgermo, B. R., \& Brønnick, K. (2013). Reading linear texts on paper versus computer screen: Effects on reading comprehension. International Journal of Educational Research, 58, 61-68.

Mashhadi, M., Rezvanfar, A., \& Yaghoubi, J. (2006). Effective factors influencing IT application by agricultural and natural resources faculty members at Tehran University. Faslnameh Pajoohesh va Barnamerizi dar Amouzesh Ali, 44, 151-168.

McDonough, S. H. (1999). Learner strategies. Language teaching, 32(01), 1-18.

Montali, J., \& Lewandowski, L. (1996). Bimodal reading: Benefits of a talking computer for average and less skilled readers. Journal of learning disabilities, 29(3), 271-279.

Movahed Mohammadi, H. \& Iravani, H. (2002). A model for internet use by graduate students of selected agricultural faculties in Iran. Iranian Journal of Agricultural Sciences, 33(4), 717-726.

Mayer, R. E. (1997). Multimedia learning: Are we asking the right questions? Educational psychologist, 32(1), 1-19.

Mayer, R. E. (2002). Multimedia learning. Psychology of learning and motivation, 41, 85-139.

National Association for the Education of Young Children (NAEYC) \& Fred Rogers Center for Early Learning and Children's Media (2012). Technology and Interactive Media as Tools in Early Childhood Programs Serving Children from Birth through Age 8. Joint position statement. Washington, DC: NAEYC; Latrobe, PA: Fred Rogers Center for Early Learning at Saint Vincent College. Retrieved from www.naeyc.org/files/naeyc/file/ sitions/PS_technology_WEB2.pdf

Navdal, F. (2007). Home-PC usage and achievement in English. Computers \& Education, 49(4), 1112-1121. http:// dx.doi.org/10.1016/j.compedu.2006.01.003

Nelson, T. (1987). Computer Lib: You can and must 
understand computers now/Dream Machines: New freedoms through computer screens-a minority report (1974). From Counterculture to Cyberculture: Stewart Brand, the Whole Earth Network, and the Rise of Digital Utopianism.

Nowak, K. L., \& Rauh, C. (2005). The influence of the avatar on online perceptions of anthropomorphism, androgyny, credibility, homophily, and attraction. Journal of Computer-Mediated Communication, 11(1), 153-178.

Noyes, J. M., \& Garland, K. J. (2003). VDT versus paper-based text: Reply to Mayes, Sims and Koonce. International Journal of Industrial Ergonomics, 31(6), 411-423.

Nunan, D. (1995). Language teaching methodology: a textbook for teachers. New York and London: Phoenix ELT.

Osín, L. (1998). Computers in education in developing countries: Why and how? Education and Technology Team, Human Development Network, World Bank.

Pavio, A. (1971). Imagery and verbal processing.

Postman, N. (1998). Five things we need to know about technological change. Denver, CO.

Prensky, M. (2001). Digital natives, digital immigrants part 1. On the horizon, 9(5), 1-6.

Rahimi, A., \& Behjat, F. (2011). On The Screen Or Printed: A Case Of EFL Learners' Online And Offline Reading The Press. i-Manager's Journal on English Language Teaching, 1(2), 5.

Rahimi, M., \& Yadollahi, S. (2011). Success in learning English as a foreign language as a predictor of computer anxiety. Procedia Computer Science, 3, 175-182.

Reinders, H. (2000). Self-access language learning in the English proficiency programme: A report on students perceptions and use of independent-learning resources. Wellington: Victoria University Wellington.

Reinders, H., \& Hubbard, P. (2012). CALL and autonomy. Affordances and constraints. Contemporary CALL. New York: Continuum.

Rice, G.E., (1994). Examining constructs in reading comprehension using two presentation modes: Paper vs. computer. Journal of Educational Computing Research, 11, 153-178.

Rasmusson, M. (2015) Reading paper-reading screen. A comparison of reading literacy in two different modes. Nordic Studies in Education, 34, 3-19.

Sakar, A., \& Ercetin, G. (2005). Effectiveness of hypermedia annotations for foreign language reading. Journal of Computer Assisted Learning, 21(1), 28-38.

Selwyn, N. (2011a). 'It's all about standardization'-Exploring the digital (re)confi uration of school management and administration. Cambridge Journal of Education, 41(4), 473-488.

Selwyn, N. (2011b). Schools and schooling in the digital age: A critical analysis. London: Routledge.

Selwyn, N. (2013). Distrusting educational technology: Critical questions for changing times. Routledge.

Sotoudehnama, E., \& Dehghan, H. (2013). The Effect of CALL Software on Iranian EFL Learners' Reading Comprehension. Iranian Journal of Language Issues
(IJLI), 1(1).

Spires, H., \& Estes, T. H. (2002). Reading in web-based learning environments. In C. C. Block \&M. Pressley (Eds.), Comprehension instruction: Research-based best practices (pp. 115-125). New York, NY: Guilford.

Suárez-Orozco, C., Suárez-Orozco, M., \& Todorova, I. (2008). Learning a new land: Immigrant students in American society. Cambridge, MA: Harvard University Press.

Tan, M., \& Lan, O. S. (2011). Teaching mathematics and science in English in Malaysian classrooms: The impact of teacher beliefs on classroom practices and student learning. Journal of English for Academic Purposes, 10(1), 5-18.

Teo, T., (2008). Pre-service teachers' attitudes towards computer use: A Singapore survey. Australasian Journal of Educational Technology, 24(4), 413-424.

Usó, E., \& Ruiz-Madrid, M. N. (2009). Reading printed versus online texts. A study of EFL learners strategic reading behavior. International Journal of English Studies, 9(2).

Veerasamy, A.K., Shillabeer, A. (2014). Teaching English Based Programming Courses to English Language Learners/Non-Native Speakers of English. International Proceedings of Economics Development and Research, 70 (4): $17-22$

Watson, W. R. (2010). Education 2.0: Breaking the mold with technology. Presentation at the Dean's Advisory Council meeting, West Lafayette, IN.

Warschauer, M. (1996). Computer-assisted language learning: An introduction. Multimedia language teaching, 3-20.

Warschauer, M. (2011). Learning in the Cloud. Teachers College Press.

Warschauer, M., \& Matuchniak, T. (2010). New technology and digital worlds: Analyzing evidence of equity in access, use, and outcomes. Review of Research in Education, 34(1), 179-225.

Wästlund, E. (2007). Experimental studies of human-computer interaction: Working memory and mental workload in complex cognition. Department of Psychology.

Wästlund, E., Reinikka, H., Norlander, T., \& Archer, T. (2005). Effects of VDT and paper presentation on consumption and production of information: Psychological and physiological factors. Computers in Human Behavior, 21(2), 377-394.

Winograd, P., Paris, S., \& Bridge, C. (1991). Improving the assessment of literacy. The Reading Teacher, 45(2), 108-116.

Wolf, G. (1996). Steve Jobs: The next insanely great thing. The Wired interview. Wired, 4(2). Retrieved February 23, 2017 from the World Wide Web: http://wwww. wired.com/w: red/toc.html

Wright, S., Fugett, A., \& Caputa, F. (2013). Using e-readers and Internet resources to support comprehension. Educational Technology \& Society, 16(1), 367-379.

Yaghoubi, J. \& Shamsaei, E. (2004). Assessing effective factors in using internet by faculty members of agricultur- 
al college, Zanjan University, Iran. Proceedings of the $20^{\text {th }}$ Annual Conference on the Association for International Agricultural and Extension Education (AIAEE), Dublin, Ireland: AIAEE, pp. 604-608.

Yanguas, I. (2009). Multimedia glosses and their effect on

L2 text comprehension and vocabulary learning. Language Learning \& Technology, 13(2), 48-67.

Zhang, Y., \& Espinoza, S. (1997). Affiliations of computer self-efficacy and attitudes with need for learning computer skills. Journal of Educational Computing Research, 17(4), 371-383.

Zucker, T. A., Moody, A. K., \& McKenna, M. C. (2009). The effects of electronic books on pre-kindergarten-to-grade 5 students' literacy and language outcomes: A research synthesis. Journal of Educational Computing Research, 40(1), 47-87.

\section{APPENDICES}

\section{APPENDIX TABLES}

Appendix A. Background questionnaire

Age:

Gender: Male-------- Female--------

\begin{tabular}{l}
\hline Access to computer: \\
\hline Background Questionnaire: Questionnaire A (percentages) \\
I have my own computer at home \\
I use the computer only at the university or public sites \\
I have never used a computer before \\
Your ability in using a computer: \\
Before this course I could: \\
Send and receive e-mails \\
Use word processor software \\
Surf the web (Persian sites only) \\
Surf the web (English sites only) \\
Surf the web (Persian and English sites only) \\
Your expectations about this reading comprehension course: \\
I am confident I can understand the basic concepts taught in this course \\
I am sure I can master the skills being taught in this class \\
Considering the difficulty of this course and my skills, I think I will do well in this class \\
I am confident I can do an excellent job on the assignments and tests in this course \\
I am certain I can understand the most difficult material in the readings in this course \\
I believe I will receive an excellent grade in this class
\end{tabular}

Appendix B. Attitude questionnaire

\begin{tabular}{|c|c|c|c|c|c|c|}
\hline \multicolumn{7}{|c|}{ Attitude Questionnaire: Questionnaire B (percentage) } \\
\hline \multicolumn{7}{|c|}{ Name: ..................... Age: .............Sex: ............ } \\
\hline & & $\begin{array}{c}\text { Strongly } \\
\text { agreed }(\%)\end{array}$ & Agreed (\%) & No idea $(\%)$ & Disagreed (\%) & $\begin{array}{c}\text { Strongly } \\
\text { disagreed }\end{array}$ \\
\hline 1 & $\begin{array}{l}\text { Being able to use the software is a } \\
\text { valuable skill }\end{array}$ & & & & & \\
\hline 2 & $\begin{array}{l}\text { I learned more computer skills because of } \\
\text { using the software }\end{array}$ & & & & & \\
\hline 3 & $\begin{array}{l}\text { I think the computer reading texts can help } \\
\text { me in reading English websites }\end{array}$ & & & & & \\
\hline 4 & $\begin{array}{l}\text { In general I learned more English because } \\
\text { of using the computer }\end{array}$ & & & & & \\
\hline
\end{tabular}


Appendix B. (Continued)

\begin{tabular}{|c|c|c|c|c|c|}
\hline Attitude Questionnaire: Questionnaire B (per & entage) & & & & \\
\hline Name: ..................... Age: .............Sex: & ............ & & & & \\
\hline & $\begin{array}{c}\text { Strongly } \\
\text { agreed (\%) }\end{array}$ & Agreed (\%) & No idea (\%) & Disagreed (\%) & $\begin{array}{c}\text { Strongly } \\
\text { disagreed }\end{array}$ \\
\hline
\end{tabular}

5 The information on the software has helped me learn English grammar

6 In comparison with the traditional method (paper-based reading comprehension) the program helped me learn vocabulary better

7 Can remember many of the new words in the reading because of the pictures accompanying them

8 Reading the English information on the software is easier than reading from textbook

9 I liked using the computer in this course

10 Use of computers in this course made it more interesting

11 I talked my classmates more because of the use of computers in this course

12 I expect to get a better grade in a reading comprehension course if using the computer becomes part of it

13 The reading texts were interesting

14 The words in other color than the text itself helped me understand the reading the reading better

15 The picture accompanying words were helpful in understanding the reading

16 The reading comprehension questions were too easy for me

17 The software I used was an easy program to learn

18 I felt confident using the software to find the information I need

19 The teacher's explanation on the use of software program was helpful

20 I was able to complete reading along without asking for help from the

21 I didn't need my teacher's help because of the use of computers

22 I could finish reading the comprehension passages in this programmm faster than paper-based reading comprehension

23 I would like to take another course that includes the use of the computer

24 I prefer to use kind of reading program even after my assignment is finished

25 The use of computer is unnecessary in this course 